\title{
CRAYFISH FEEDING PREFERENCES FOR FRESHWATER MACROPHYTES: THE INFLUENCE OF PLANT STRUCTURE AND CHEMISTRY
}

\author{
Author(s): Greg Cronin, David M. Lodge, Mark E. Hay, Margaret Miller, Anna \\ M. Hill, Thomas Horvath, Robin C. Bolser, Niels Lindquist, and Martin Wahl \\ Source: Journal of Crustacean Biology, 22(4):708-718. 2002. \\ Published By: The Crustacean Society \\ DOI: http://dx.doi.org/10.1651/0278-0372(2002)022[0708:CFPFFM]2.0.CO;2 \\ URL: http://www.bioone.org/doi/ \\ full/10.1651/0278-0372\%282002\%29022\%5B0708\%3ACFPFFM\%5D2.0.CO \\ $\% 3 \mathrm{~B} 2$
}

BioOne (www.bioone.org) is a nonprofit, online aggregation of core research in the biological, ecological, and environmental sciences. BioOne provides a sustainable online platform for over 170 journals and books published by nonprofit societies, associations, museums, institutions, and presses.

Your use of this PDF, the BioOne Web site, and all posted and associated content indicates your acceptance of BioOne's Terms of Use, available at www.bioone.org/page/ terms_of use.

Usage of BioOne content is strictly limited to personal, educational, and non-commercial use. Commercial inquiries or rights and permissions requests should be directed to the individual publisher as copyright holder. 


\title{
CRAYFISH FEEDING PREFERENCES FOR FRESHWATER MACROPHYTES: THE INFLUENCE OF PLANT STRUCTURE AND CHEMISTRY
}

\author{
Greg Cronin, David M. Lodge, Mark E. Hay, Margaret Miller, Anna M. Hill, \\ Thomas Horvath, Robin C. Bolser, Niels Lindquist, and Martin Wahl
}

(GC, MEH, MM, RCB, NL, MW) University of North Carolina at Chapel Hill, Institute of Marine Sciences, Morehead City, North Carolina 28557 U.S.A.; (GC, DML, AMH, TH) University of Notre Dame, Department of Biological Sciences, Notre Dame, Indiana 46556 U.S.A. Current addresses: (GC) Department of Biology, University of Colorado at Denver, Denver, Colorado 80217; (MEH) School of Biology, Georgia Institute of Technology, Atlanta, Georgia 30332-0230; (MM) NMFS/SFSC, 75 Virginia Beach Dr., Miami, Florida 33149; (AMH) Department of Biology, The University of Louisiana at Monroe, Monroe, Louisiana 71209; (TH) Biology Department, SUNY-Oneonta, Oneonta, New York 13326; (RCB) Sierra Nevada Aquatic Research Laboratory, University of California, Mammoth Lakes, California 93546; (MW) Institute of Marine Sciences, Duesternbrookerweg 20, D-24105, Kiel, Germany (Corresponding author (GC) e-mail: gcronin@carbon.cudenver.edu)

\begin{abstract}
A B S T R A C T
The omnivorous crayfish Procambarus clarkii fed selectively on several species of macrophytes, preferring delicate fresh plants that had filamentous or finely-branched architectures. When the macrophytes were dried, powdered, and reconstituted into an alginate gel (thus eliminating amongspecies differences in physical characteristics), crayfish preferences were altered; previously tough plants that were high in nitrogen and protein were preferred over previously delicate plants that were low in nitrogen and protein. Even though plant structure influences feeding decision of crayfish, the structurally identical macrophyte gels were fed upon differently, demonstrating that nonstructural traits are important feeding determinants. However, plant tissue constituents such as nitrogen, protein, phenolics, lignin, cellulose, or ash were not significantly correlated with feeding preferences. Two high-nitrogen plants that were avoided by crayfish as fresh and as reconstituted tissue (Nuphar luteum macrophyllum and Alternanthera philoxeroides) possessed extracts that reduced crayfish feeding in laboratory assays, demonstrating that macrophyte metabolites can deter some herbivores. As is often observed with large generalist herbivores and omnivores in terrestrial and marine systems, the freshwater crayfish made feeding decisions based upon multiple plant cues (structure, nutrition, chemical defenses).
\end{abstract}

Herbivores are an important component of the food webs of nearly all communities that receive sunlight. Recent reviews of macrophyte-herbivore interactions in freshwater systems have noted that herbivory is more intense in freshwater habitats than was previously assumed, and these authors have called for a better mechanistic understanding of this first trophic link (Lodge, 1991; Newman, 1991; Lodge et al., 1998). A better understanding of macrophyte-herbivore interactions is important for predicting how herbivores modify the functional role of macrophytes in aquatic ecosystems and could be useful in regulating desirable and nuisance macrophytes (Carpenter and Lodge, 1986). Basic information about feeding selectivity of herbivores and plant defenses from freshwater systems will contribute to among-system comparisons that have already been made for terrestrial and marine systems, providing general insights into the ecology and evolution of plant-herbivore interactions (Hay and Steinberg, 1992; Lodge et al., 1998).

Little quantitative information exists about the feeding preferences of freshwater herbivores, and less is known about plant traits that determine those preferences (Lodge, 1991; Newman, 1991), although macrophyte structure (Chambers et al., 1991; Cronin, 1998), nutritive value (Fraser et al., 1984; Doucet and Fryxell, 1993; Kreider and Watts; 1998), and secondary metabolites (Buchsbaum et al., 1984; Newman et al., 1992; Bolser et al., 1998; Cronin, 1998) have all been implicated. As an example of our dismal mechanistic 
understanding of freshwater macrophyte-herbivore interactions, thousands of secondary metabolites have been characterized from terrestrial and marine plants, and the effects of dozens of these compounds on the feeding behavior of terrestrial (Rosenthal and Berenbaum, 1992) and marine (McClintock and Baker, 2001) herbivores are known, but there are only two documented examples of a specific plant compound defending a freshwater macrophyte from herbivores (Newman et al., 1992; Bolser et al., 1998). Nevertheless, there is no compelling reason to expect chemical defenses to be rarer in freshwater than in terrestrial or marine plants (Ostrovsky and Zettler, 1986; Lodge et al., 1998).

Crayfishes are very common and important freshwater omnivores that consume much living plant tissue and plant detritus when favored animal prey is not available (Hobbs, 1993; Momot, 1995). They can greatly reduce the standing stock of aquatic plants and the density of benthic invertebrates (Lodge and Lorman, 1987; Chambers et al., 1990; Hobbs, 1993; Creed, 1994; Lodge et al., 1994), yet little is known about their feeding selectivity or the effects of various plant traits on their feeding decisions. In this study, we examined the feeding preferences of the crayfish Procambarus clarkii (Giard, 1852) among 14 species of freshwater macrophytes (including macroscopic algae) and measured their responses to manipulation of the combined plant traits of morphology, toughness, and surface features (hereafter grouped as "structure") and their response to plant chemistry. We also relate the preference of crayfish with measurements of plant phenolics, protein, nitrogen, fiber, lignin, cellulose, ash, and carbon. By determining feeding preferences and associated plant traits, we sought mechanistic insights into macrophyte-crayfish interactions.

\section{Materials AND Methods}

\section{The Organisms}

Fourteen plant species that represented a wide range of growth forms and taxonomic groups were used in this study. All plants were collected from aquatic or terrestrial habitats in coastal North Carolina, returned to the Institute of Marine Sciences (IMS) in coolers, and in most cases were used in feeding assays within $48 \mathrm{~h}$. When it was necessary to store plants for more than $48 \mathrm{~h}$, entire live plants were transplanted into a 1,200-1 flow-through mesocosm. Five of the plants were submersed forms, including three algae (Chara sp. (Charophyta); Oedogonium sp.; and an unknown chlorophyte (Chlorophyta)) and two angiosperms (Egeria densa and Ceratophyllum demersum (Magnoliophyta)). We used submersed leaves of two heterophyllous macrophytes (Myriophyllum pinnatum (Haloragaceae) and Potamogeton pulcher (Potamogetonaceae)). Seven aquatic macrophytes were angiosperms with floating (Nuphar luteum macrophyllum and Nymphaea odorata) or emergent (Typha latifolia, Sagittaria graminea graminea, Alternanthera philoxeroides, and Nasturtium officinale) leaves. The remaining plant, Hydrocotyl bonariensis (Umbelliferae), was terrestrial. Plant species are listed in Table 1 and are named according to Beal (1977).

The historic native range of $P$. clarkii did not include the coastal plain of North Carolina. However, this commercially valuable crayfish has been cultivated far outside its native range and now occurs as feral populations in Central and South America, Europe, Africa, Asia, Atlantic and Indopacific islands, and across the continental U.S.A. (Hobbs, 1972; Huner and Barr, 1984). Our crayfish came from a managed wetland near Trenton, North Cardina (about $40 \mathrm{~km}$ from IMS). We held them individually in $24 \times 32 \mathrm{~cm}$ plastic tubs with about 5-cm depth of dechlorinated tap water. Crayfish used in these experiments had a carapace length of 39-56 $\mathrm{mm}$ and were maintained on commercial fish food between assays. The crayfish had access to food until a few minutes to $2 \mathrm{~h}$ prior to assays to avoid unnaturally high levels of hunger, which can influence feeding selectivity (Cronin and Hay, 1996a).

\section{Crayfish Preference Among Fresh Plants}

Fresh pieces of 14 macrophyte species were simultaneously offered to individual crayfish to determine their feeding preferences. Only one piece of any individual plant was used for the assay in order to maintain independence among replicate crayfish. We used pieces of plants that appeared to occupy similar volumes of water in an attempt to provide comparable encounter rates to the crayfish. This procedure resulted in different masses of some plant species being used during assays because of morphological differences among macrophytes. Interspecific range of mass for plant pieces was $100-300 \mathrm{mg}$. A weighed piece of each of the 14 macrophyte species was placed in each of 15 plastic tubs $(24 \times 32 \mathrm{~cm}$ with 5 -cm depth of de-chlorinated tap water) with an individual crayfish. To control for changes in plant mass not due to crayfish, 15 tubs were set up in an identical manner, but without a crayfish. The pieces of plants were anchored to tub bottoms with rubber suction cups in a nonbiased arrangement.

After crayfish foraged for $2 \mathrm{~d}$, macrophytes were reweighed, and the amount of tissue removed was calculated with the following equation $\left.\left[\left(\mathrm{H}_{0} \times \mathrm{C}_{\mathrm{f}} / \mathrm{C}_{0}\right)-\mathrm{H}_{\mathrm{f}}\right)\right]$; where $\mathrm{H}_{0}$ and $\mathrm{H}_{\mathrm{f}}$ were the mass of the plants exposed to herbivory before and after the assay, respectively, and $\mathrm{C}_{0}$ and $\mathrm{C}_{\mathrm{f}}$ were the mass of the macrophyte species from a paired control tub before and after the assay. The amount of tissue destroyed by crayfish included material that was consumed plus material that was shredded during feeding (nonconsumptive destruction). Data from the multiple-choice feeding assays cannot be analyzed with parametric statistics because the assumption of independence among treatments (i.e., macrophyte species) is violated (Peterson and Renaud, 1989). Therefore, $P$-values and multiple comparisons groupings were calculated with a nonparametric Friedman test based on rank scores of preferences $(\alpha=0.05$; Conover, 1980). The Friedman test assumes independence among blocks (i.e., replicate crayfish), which our experimental design provided. 


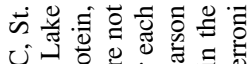

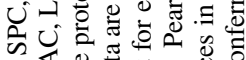

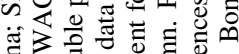

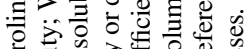
记

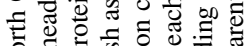

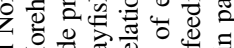

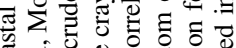

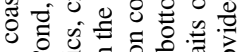
$\Xi 2.0$.

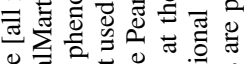

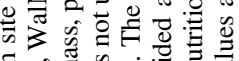

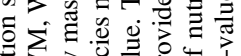

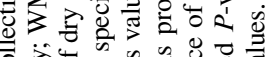

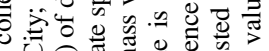

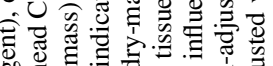

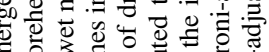

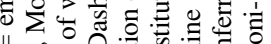

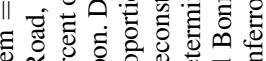

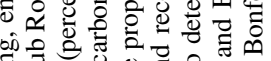

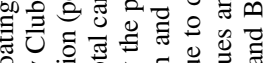

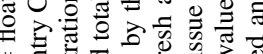
II U.

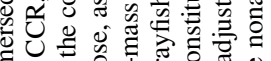

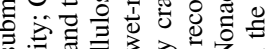

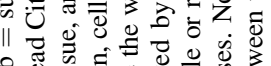

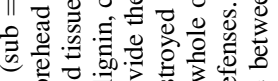

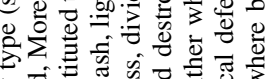

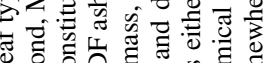
ब

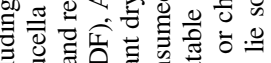

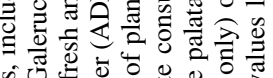

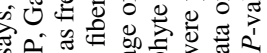

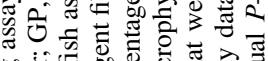

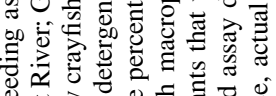

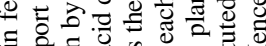

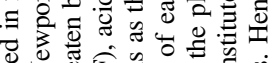

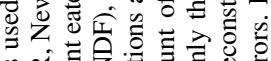

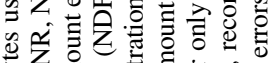
希记

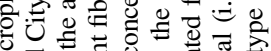

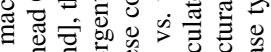

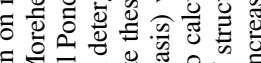

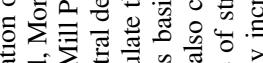

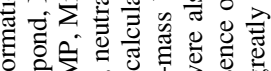

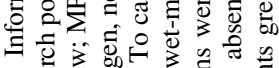

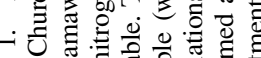

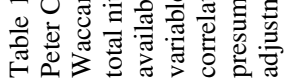

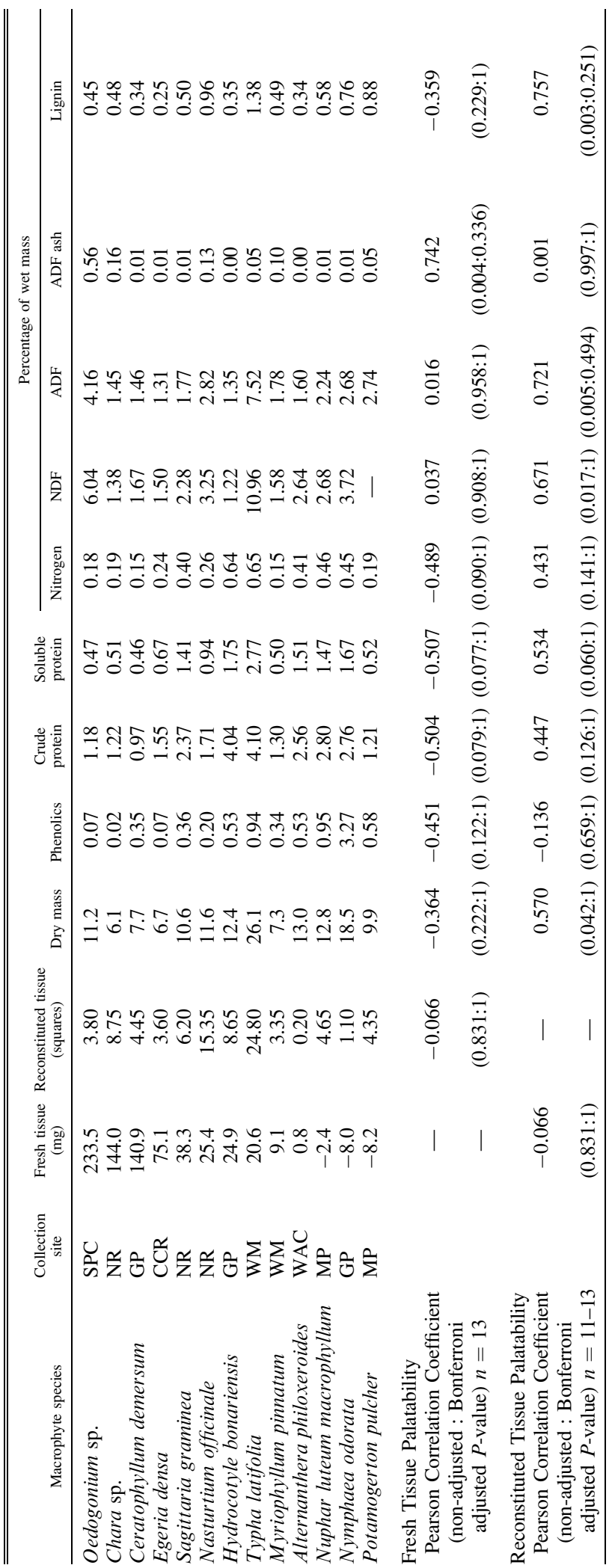




\section{Crayfish Preference Among Reconstituted Plants}

To determine whether plant structure influences crayfish feeding decisions, additional material from the above plant collections was frozen, freeze-dried, ground into a fine powder, and stored at $-25^{\circ} \mathrm{C}$. The powdered macrophytes were reconstituted in an alginate gel at natural dry mass concentration using methods modified from Hay et al. (1998). The measured amount of powdered macrophyte (this varied among macrophyte species as dry mass/wet mass varied among species) was mixed into a $4 \%$ solution of sodium alginate. This mixture was formed into $2.6 \mathrm{~cm} \times$ $60 \mathrm{~cm} \times 1.5 \mathrm{~mm}$ strips on a piece of Fiberglass window screening material that provided support and a uniform grid that allowed us to quantify the amount eaten by counting the squares of the screen that had been cleared of reconstituted plants. A solution of calcium chloride $(0.25 \mathrm{M})$ was sprayed onto the macrophyte/sodium alginate mixture to cause it to solidify (sodium alginate is soluble in water, calcium alginate is a water-insoluble gel). Thus, all reconstituted macrophytes were of similar morphology and toughness, but the nutritive value and taste of each reconstituted species was altered as little as possible (but see Discussion). Because food squares were not lost from the screen grid in the absence of grazers, problems associated with autogenic changes (Peterson and Renaud, 1989) were avoided.

The strips of 13 reconstituted plants (there was not enough of the unidentified chlorophyte for this experiment) were cut into $1.2-\mathrm{cm}$-long sections, anchored to the bottom of tubs with rubber suction cups, and simultaneously offered to 30 separate crayfish. The 11 replicates in which crayfish did not consume any reconstituted plants during the 10-h assay were excluded from data analysis, resulting in a sample size of 19 . These consumption data were analyzed with a Friedman test.

\section{Effects of Macrophyte Chemistry on Crayfish Feeding}

The effects on crayfish feeding of crude chemical extracts from Nuphar luteum macrophyllum (floating/emergent leaves) and Alternanthera philoxeroides (emergent) were assessed by adding extracts at natural concentrations to a standard, palatable agar-based food with a ratio of $1 \mathrm{~g}$ Typha powder : $7.3 \mathrm{ml} \mathrm{H}_{2} \mathrm{O}: 0.17 \mathrm{~g}$ agar. These two macrophytes were chosen because they were low-preference foods as whole tissue and reconstituted tissue and they were used by specialist insects (Galerucella nymphaeae and Donacia sp. on Nuphar and Agasicles hygrophila on Alternanthera) at our field sites. For these experiments, agar was used instead of alginate because the former made a firmer food. Nuphar and Alternanthera were extracted separately, twice with methanol and twice more with 1:1 methanol : ethylacetate. After removing the organic solvents with a rotary evaporator, a water : ethylacetate partition was performed, yielding a lipophilic crude extract and a watersoluble crude extract. For Nuphar, a portion of the lipophilic crude extract was fractionated further using silica-gel flash column chromatography. Ten fractions of increasing polarity were eluted sequentially with two column volumes each of $1: 4,2: 3,3: 2$, and $4: 1$ ether : hexanes, $100 \%$ ether, $3 \%, 7 \%, 12 \%$, and $20 \%$ methanol in ether, and finally 1:1 acetone : methanol. Extracts and fractions were dried with a rotary evaporator, weighed, dissolved in a minimal amount of ether, and stored at $-25^{\circ} \mathrm{C}$ until used. Fraction 10 formed a solid coagulate when stored in the freezer. The coagulate and remaining material in fraction 10 were assayed separately and in combination.
Natural concentrations of lipophilic compounds (i.e., extract or fraction from $1 \mathrm{~g}$ plant was added to $1 \mathrm{~g}$ artificial food) were added to the standard Typha food by placing the freeze-dried Typha in a small flask, adding the required amount of the extracts dissolved in diethyl ether, adding more ether until it covered the powdered Typha, and then removing the ether with a rotary evaporator. This resulted in a uniform coating of test extracts on the Typha particles prior to their being added to the agar mixture. The composition of flash column fractions was qualitatively assessed with thin-layer chromatography (TLC), and fractions of similar TLC characteristics were tested in combination in feeding assays in an attempt to test compounds near natural concentrations. Combining fractions helped avoid the situation where a compound found in three flash column fractions might be tested at only $33 \%$ natural concentration if fractions were tested in three separate assays. Watersoluble extracts were added to treated foods by replacing distilled water in the recipe with the appropriate volume of water-soluble extract. Control Typha food was treated identically but without addition of the extract.

Artificial foods for testing extracts were made by pouring heated Typha-agar-water mixture into a mold as previously described. In each assay, food treated with extract was poured into one opening of the mold, and control food (without extract) was poured into a second strip in the mold separated by $1.3 \mathrm{~cm}$. The food gelled as it cooled. The screen was then cut perpendicularly to the $60-\mathrm{cm}$ axis so that a test strip of screen would contain equal-size rectangles of both treatment and control foods (112 screen squares each). The test strips were offered to individual crayfish until approximately half the available food was consumed (typically 1 to $12 \mathrm{~h}$, depending on feeding rates of individual crayfish), and the amount of artificial food consumed was quantified by counting the squares in the screen that had been cleared of food. Data for each of these feeding assays were analyzed with a paired-sample $t$-test. Directed $P$-values (Rice and Gaines, 1994) were used because we predicted that crayfish would be deterred by the extracts, given that both Nuphar and Alternanthera were low-preference foods in assays with both whole and reconstituted tissue (see Results).

\section{Plant Tissue Constituents}

Several tissue properties known to influence feeding of terrestrial or marine herbivores were measured for the macrophytes used in our assays. Powdered macrophytes (i.e., a pooled collection of at least ten individuals for each species) were analyzed for total nitrogen and carbon with a Perkin Elmer CN analyzer (model 2400). Fiber, cellulose, lignin, and ash were quantified gravimetrically (Goering and Soest, 1970). Soluble protein was measured using a modified Bradford (1976) assay (Cronin and Hay, 1996b), and phenolics were quantified using a modified Folin-Denis assay (Ragan and Craigie, 1978, see below). All analyses were performed in duplicate, with the mean value used as the datum for each variable.

For phenolic analyses, 5-6 mg samples of freeze-dried, ground tissue, weighed to the nearest $0.1 \mathrm{mg}$, were extracted with $1.00 \mathrm{ml}$ of $50 \%$ aqueous methanol for $1 \mathrm{~d}$ at $1{ }^{\circ} \mathrm{C}$ with occasional mixing. $100 \mu \mathrm{l}$ of the extraction solution were placed in a test-tube with $8.4 \mathrm{ml}$ of $\mathrm{dH}_{2} \mathrm{O}$, and $0.5 \mathrm{ml}$ of Folin-Denis reagent was added. After $3 \mathrm{~min}, 1.0 \mathrm{ml}$ of saturated sodium carbonate solution was added, and after $20 \mathrm{~min}$, absorbance at $760 \mathrm{~nm}$ was measured. The concentration of phenolics was calculated using tannic acid as a standard. 


\section{RESULTS}

\section{Crayfish Preference Among Fresh Plants}

Procambarus clarkii was a sloppy feeder, fragmenting some plant tissue that was not consumed. Although consumption was less than tissue loss, the two were positively related as crayfish shredded plants in the process of feeding. Thus, we feel tissue loss is a good measure of palatability. Crayfish fed on several macrophyte species, including chlorophytes, a charophyte, and angiosperms (Fig. 1), a pattern consistent with the generalized feeding habits of crayfish (Huner and Barr, 1984; Cronin, 1998; Gutierrez-Yurrita et al., 1998). Though Procambarus clarkii is a generalist feeder, it showed strong feeding preferences by consuming large amounts of some species and completely avoiding others (Fig. 1). The two chlorophyte species were most preferred (as whole tissue), followed by Chara and two angiosperms with highly branched and/or narrow leaves (Ceratophyllum and Egeria). The remaining species that were less preferred consisted of angiosperms with large, flat or bladelike leaves, with the exception that submersed Myriophyllum leaves were narrow. Thus, it appears that plant architecture may be an important feeding determinant for $P$. clarkii.

\section{Crayfish Preference Among Reconstituted Plants}

The feeding preferences of Procambarus clarkii were altered markedly when reconstituted macrophytes were offered (Fig. 1). No correlation existed between the palatability of plants as whole vs. reconstituted tissue (Pearson correlation coefficient $=-0.066 ; P=$ 0.831; Table 1). While all species of the reconstituted macrophytes had similar physical characteristics (i.e., they were a gel), their taste and nutritional properties were modified as little as possible and were presumably similar to whole tissue (but see Discussion), and thus varied among macrophyte species. Some macrophytes that had been little consumed as whole tissue (e.g., Typha and Nasturtium) were highly preferred as reconstituted foods. Other species that were highly preferred as whole tissues (e.g., Oedogonium and Ceratophyllum) were less preferred as reconstituted foods (Fig. 1). That feeding preferences were altered when physical traits were altered confirms that plant structure is an important feeding determinant for P. clarkii. That structurally similar reconstituted foods were fed upon differently shows that factors other than structure (e.g., secondary chemistry and nutrition) also are important feeding determinants.

\section{Effects of Macrophyte Chemistry on Crayfish Feeding}

Nuphar luteum macrophyllum and Alternanthera were considered good candidates for possessing chemical defenses because they were relatively high in protein and nitrogen (Table 1), yet were little consumed as whole or as reconstituted tissue (Fig. 1). Chemical extracts from each macrophyte species significantly reduced feeding by $P$. clarkii (Figs. 2, 3). Although not all fractions were deterrent, Nuphar contained multiple deterrent compounds as evidenced by multiple deterrent flash chromatography fractions that covered a wide range of polarities (Fig. 2). The water-soluble extract of Nuphar was not assayed here, though in a separate study, Bolser and Hay (unpublished data) found the water-soluble extract from Nuphar to reduce crayfish feeding by $90 \%$. Alternanthera too was likely defended by multiple compounds given that the lipophilic and the water-soluble extracts were each deterrent (Fig. 3).

\section{Plant Tissue Constituents}

Every plant trait that we measured (dry mass, phenolics, crude and soluble protein, total nitrogen and carbon, neutral detergent fiber (NDF), acid detergent fiber (ADF), ADF ash, lignin, cellulose, and ash) differed considerably among macrophytes (Table 1 ). The correlation between tissue constituents and the amount of plant consumed depended on whether concentrations were expressed on a dry mass basis or a wet mass basis (because the macrophytes varied in their water content) and whether or not the traits were correlated with consumption of fresh or reconstituted tissue (because preferences differed between these feeding assays). We report tissue constituents and their correlations with feeding based on wet mass concentrations because crayfish were offered hydrated food. Those interested in dry mass concentrations can divide wet mass concentrations by the proportion of dry mass: Table 1 provides all the needed information.

Because correlations between feeding and plant traits were made for several characteristics, the likelihood of making a type I error was increased. Procedures such as Bonferroni 


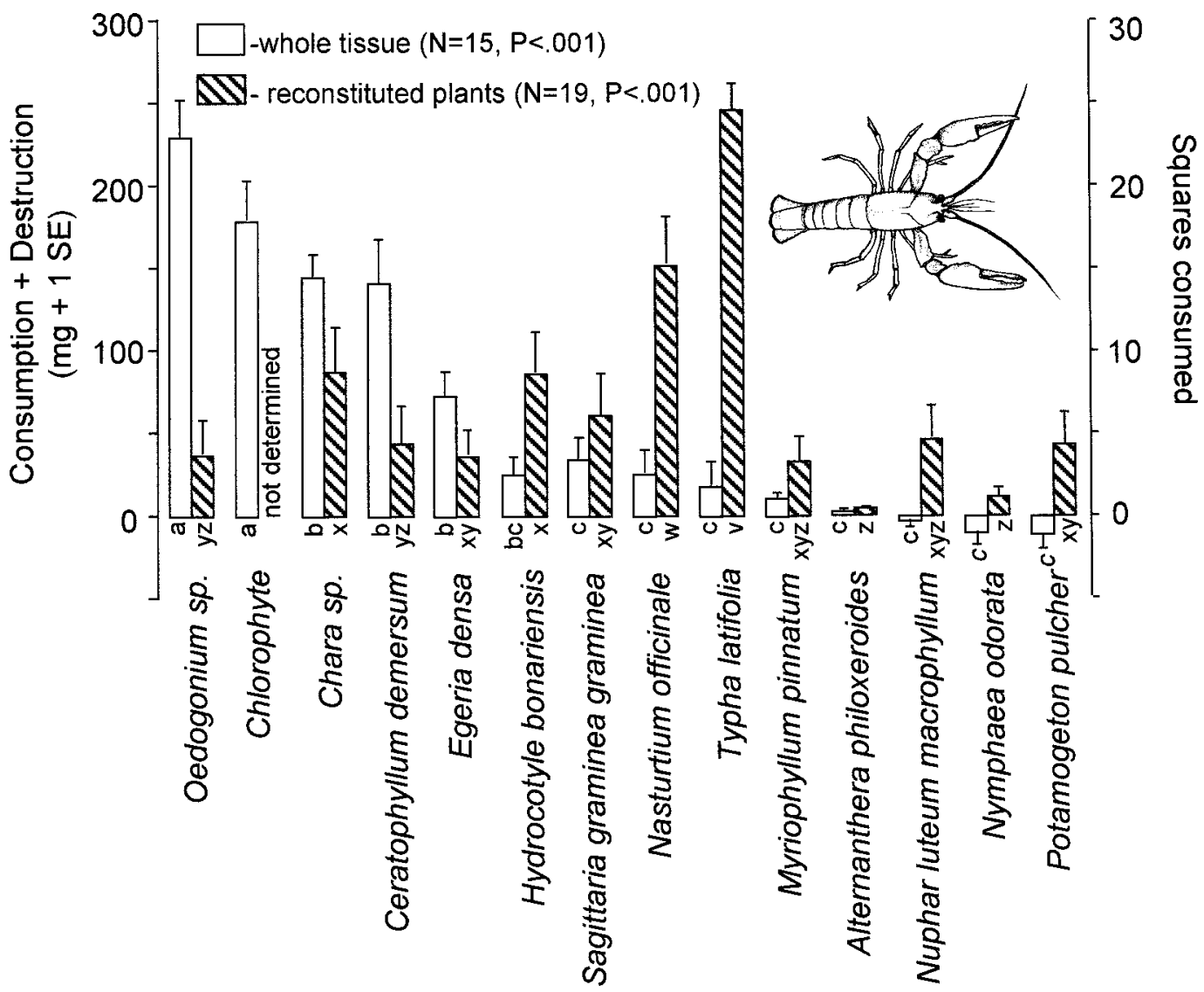

Fig. 1. Feeding (including nonconsumptive destruction) by Procambarus clarkii when offered a choice of macrophyte species. Plants were offered as fresh tissue (open bars, left axis) or as freeze-dried, powdered macrophytes that had been reconstituted with an alginate gel (hatched bars, right axis). Bars represent mean $(+1 \mathrm{SE})$. Letters below bars represent statistical groupings (Friedman test at $\alpha=0.05$ ): a-c for fresh tissue; $\mathrm{v}-\mathrm{z}$ for reconstituted tissue.

adjusts $P$-values to account for multiple correlations such that the likelihood of making a type I error does not increase. As a consequence, Bonferroni adjustments greatly increase the chance of committing a type II error. We provide both nonadjusted and Bonferroniadjusted $P$-values in Table 1: actual $P$-values lie somewhere between these two $P$-values. Some trends in correlations are described below.

Several tissue traits had negative correlation coefficients when compared to feeding during the whole-tissue assay, but had positive correlation coefficients when compared to feeding during the reconstituted-tissue assay. As examples, traits probably associated with the nutritive value of plants, such as the percentage of dry mass, soluble protein, crude protein, and total nitrogen, were all negatively related to the amount of fresh tissue consumed, though not significantly. However, each of these nutritive traits had positive correlation coefficients with the quantity of reconstituted food eaten. In contrast to this pattern with nutritive traits, phenolic (a group of putative defensive compounds) concentrations had negative correlation coefficients with the amounts of macrophytes consumed as both whole and reconstituted tissue (Table 1). For crayfish preferences among the reconstituted macrophytes, some of the higher correlation coefficients were observed for structural compounds (e.g., lignin, fiber, cellulose) (Table 1).

\section{DisCUSSION}

Procambarus clarkii is an omnivorous creature that demonstrated clear feeding preferences among macrophyte species. Like most generalist feeders, $P$. clarkii used multiple prey traits 


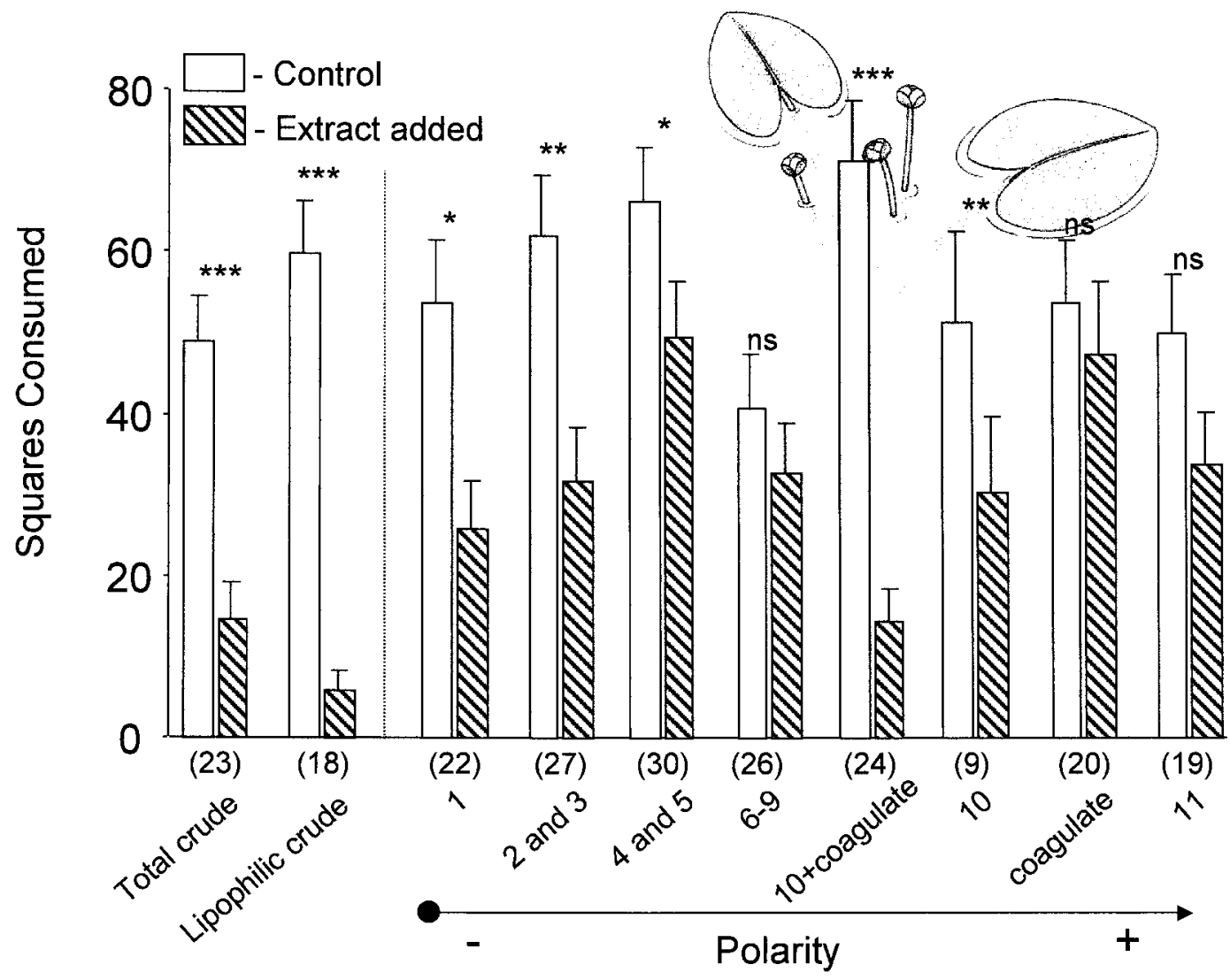

Fig. 2. The effects of floating-leafed Nuphar luteum macrophyllum total crude extract, lipophilic crude extract, and numbered flash-column fractions of the lipophilic extract on feeding by Procambarus clarkii. Each pair of bars represents the mean $(+1 \mathrm{SE})$ amount of control and treated food consumed during an assay. Sample sizes are indicated below each pair of bars. NS, $P_{\mathrm{dir}}>0.05 ; *, P_{\mathrm{dir}}<0.01 ; * *, P_{\mathrm{dir}}<0.001 ; * * *, P_{\mathrm{dir}}<0.0001$.

as proximal cues for making feeding decisions, and no single trait was a good predictor of palatability. Generalist herbivores or omnivores, including P. clarkii, base their feeding decisions on multiple plant traits such as morphology, structure, chemical defenses, and nutritive value (Mattson, 1980; Lodge, 1991; Newman, 1991; Doucet and Fryxell, 1993; Bolser et al., 1998; Cronin, 1998; Kreider and Watts, 1998; Lodge et al., 1998). Procambarus clarkii fed on plants such as Oedogonium, Chara, Ceratophyllum, and an unidentified chlorophyte when offered as whole tissue, apparently because their finely branched or filamentous morphologies make them easier to handle and consume. When the difficulties imposed by plant structure were removed by forming all plants into a gel, the feeding preferences of $P$. clarkii were altered; some plants with characteristics likely to be positively related to nutritive value (e.g., high concentrations of protein, nitrogen, and dry mass), such as Typha and Nasturtium, became more favored food items, and some less nutritious plants such as Oedogonium and Ceratophyllum became less favored. Macrophytes with high concentrations of protein, nitrogen, and dry mass that were low preference as whole and reconstituted plants (e.g., Nuphar and Alternanthera) contained chemical defenses (Figs. 2, 3). Nuphar and Alternanthera were chemically defended against $P$. clarkii by multiple compounds. Five fractions of Nuphar lipophilic extract representing different polarities deterred feeding by the crayfish (Fig. 2). Both lipophilic and water-soluble extracts of Alternanthera also deterred the crayfish (Fig. 3).

Our methods were not sufficient to identify specific defensive compounds. Such detailed understanding of plant defenses is extremely 


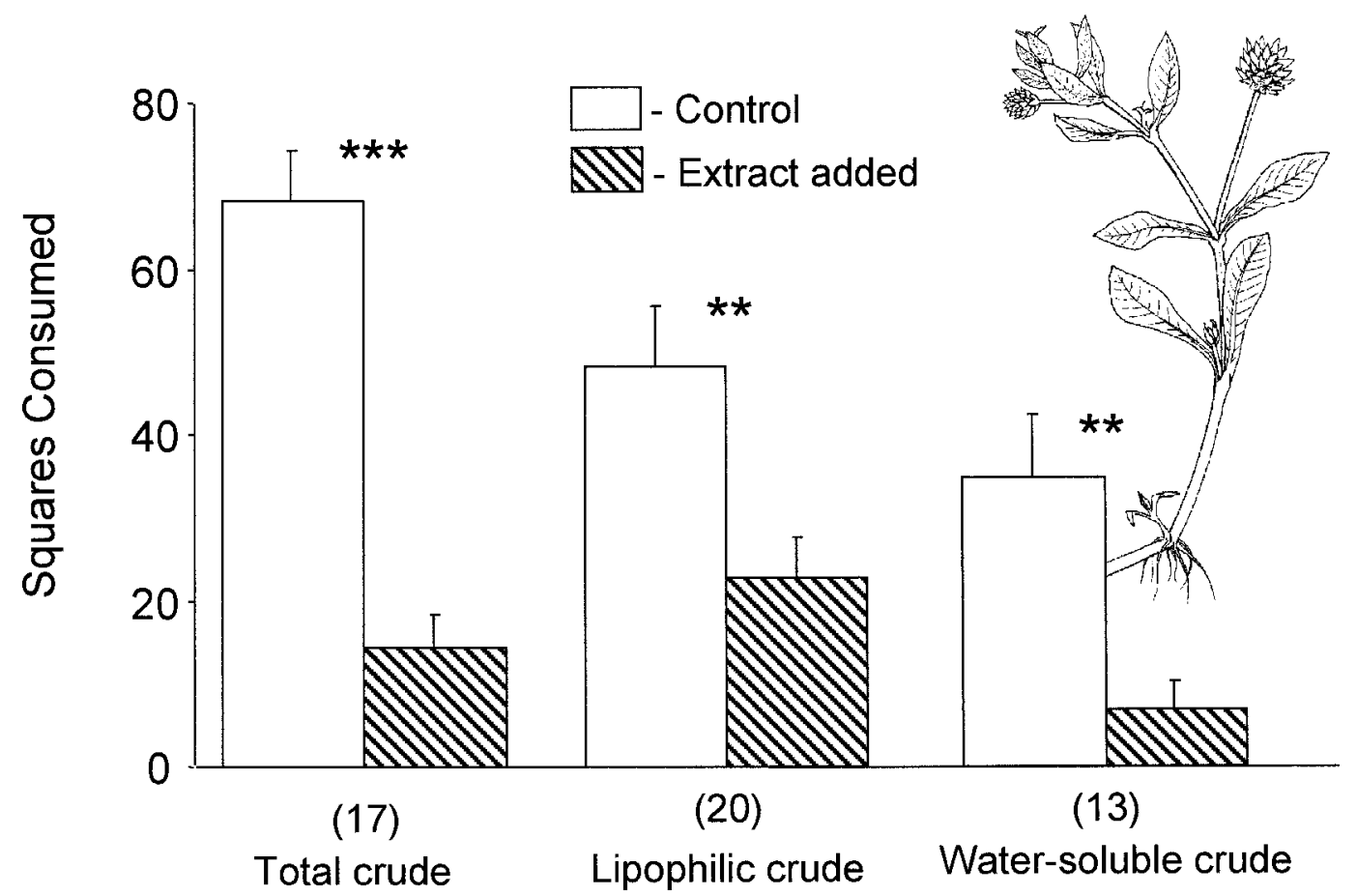

Fig. 3. The effects of Alternanthera philoxeroides total crude extract, lipophilic crude extract, and water-soluble crude extract on feeding by Procambarus clarkii. Each pair of bars represents the mean ( $+1 \mathrm{SE})$ amount of control and treated food consumed during an assay. Sample sizes are indicated below each pair of bars.

useful in interpreting observations, quantifying intraspecific variation in defenses, and detecting procedural artifacts. For example, Nasturtium (watercress) is one of two species of aquatic plant from which a specific mechanism of chemical defense has been identified (Newman et al., 1992). It possesses the glucosinolate-myrosinase system. Without that knowledge, we might have interpreted the observation that Procambarus clarkii avoids fresh Nasturtium but prefers freeze-dried, reconstituted Nasturtium over other species to mean that the plant is structurally, but not chemically, defended. However, freeze-drying deactivates myrosinase, preventing the conversion of glucosinolate to its nitrile and deterrent isothiocyanate (Newman et al., 1992). Similar activation of chemical defense, apparently due to enzymes released by cell damage, is also known for other chemical defenses in seaweeds (Paul and Van Alstyne, 1992) and terrestrial plants (Karban and Baldwin, 1997). The likely reason that $P$. clarkii readily consumed reconstituted Nasturtium is that we deactivated the plant's chemical defense system, not that the plant was not defended. Thus, our assumption that reconstituted plants are similar to fresh plants regarding taste and nutritive value is not always valid. A better mechanistic understanding of plant defenses and potential chemical artifacts is needed to determine when such assumptions are invalid (Cronin et al., 1995).

Whether reconstituted Typha latifolia was preferred because it is not chemically defended or because any defenses were deactivated cannot be determined from our experiments. Similar to our results, Cronin (1998) and Bolser et al. (1998) found that Typha spp. were preferred by $P$. clarkii as reconstituted foods; however, the chemical extract of $T$. latifolia stimulated crayfish feeding (Cronin, 1998), whereas the extract of $T$. angustifolia deterred crayfish feeding (Bolser et al., 1998). Despite the drawbacks of undetected artifacts, we believe that the methods we used are an efficient screening device adequate to discover some general patterns about the roles in herbivore feeding choices of structural, chemical, and other plant constitutents. Such bioassays can be useful in guiding the search and isolation of specific bioactive compounds. 
Procambarus clarkii will eat only plants that it can handle, shred, and ingest. Although this is self-evident, it may explain why feeding preferences during the whole-tissue assay were negatively, but nonsignificantly, related to plant traits normally considered to be feeding stimulants, such as protein, nitrogen, and dry mass (Mattson, 1980). Plants with high concentrations of dry mass, and hence high concentrations of nutrients on a wet-mass basis, also had high amounts of structural material. After the plants were made structurally identical, the sign of the correlation coefficient between nutritive plant traits and crayfish feeding preferences switched from negative to positive (Table 1). Although P. clarkii apparently avoided structurally tough fresh plants (i.e., macrophytes with thick, flat leaves), structural compounds such as lignin, fiber, and cellulose were positively related, though not always significantly, to the palatability of reconstituted plants that had similar, low toughness (Table 1). Thus, it seems to be the physical toughness of structural compounds that reduces grazing of fresh tissues by $P$. clarkii, not chemical distastefulness or indigestibility of the compounds. Chambers et al. (1991) found that the feeding preferences of the crayfish Orconectes virilis also were negatively correlated with plant nutritive value, probably because the less nutritious plants were easier to handle. The importance of plant structure in determining its susceptibility to grazing has also been previously noted for seaweeds; hard encrusting forms are among the least susceptible to herbivores, whereas highly branched or filamentous forms are generally the most susceptible (Littler and Littler, 1980).

Reduction in the structural integrity of macrophytes following death helps explain why macrophytes are consumed more as detritus than as living tissue, an explanation that receives less attention than the "microbial conditioning" or "chemical-defense leaching" explanations (Newman, 1991). The importance of plant structure may also help explain why crayfish reduce the standing stock of submersed vegetation more than of emergent vegetation, given that emergent vegetation has more structural material (Lodge and Lorman, 1987; Chambers et al., 1990; Creed, 1994; Lodge et al., 1994).

Factors other than plant tissue quality, such as cover or protection from predators afforded by the plant (Damman, 1987; Duffy and Hay, 1994), the consumer's state of hunger (Cronin and Hay, 1996a), or the consumer's prior feeding experiences (Provenza, 1995; Dorn et al., 2001) also will affect herbivore feeding decisions. Although a single plant trait (e.g., thick, tough, blade-like leaf structure) can be used to predict accurately a plant's susceptibility to Procambarus clarkii, it may not be useful to predict a plant's susceptibility to herbivory in general because the effects of plant traits on feeding vary among herbivore species. Additionally, multiple plant traits can interact to influence herbivore feeding behavior in a mitigative, additive, or synergistic manner (Duffy and Paul, 1992; Hay et al., 1994).

It has been demonstrated that the feeding activity of generalists can have significant direct and indirect impacts on aquatic communities (Lodge and Lorman, 1987; Chambers et al., 1990; Creed, 1994; Lodge et al., 1994; Hill and Lodge, 1995). A mechanistic understanding of macrophyte-herbivore interactions will improve our ability to predict the impacts of herbivores on freshwater communities. We know that herbivores can reduce the standing stock of macrophytes, but a knowledge of herbivore feeding preferences and plant defensive traits will allow better herbivore-specific and macrophyte-specific predictions of impact.

\section{ACKNOWLEDGEMENTS}

This research was funded by NSF DEB94-08452 (to DML) and NSF OCE92-02847 (to MEH). We are grateful to Joe Burns for analyzing macrophyte samples and to Mr. C. E. Ballenger for donating crayfish. Mike Klompas, Walter Waters, Erin Siska, and Keith Bayha helped with experiments. Illustrations of plants are from the Aquatic Plant Information Retrieval System, and Procambarus was drawn by Robin Bolser. Thoughtful comments from anonymous reviewers improved the manuscript.

\section{Literature Cited}

Beal, E. O. 1977. A Manual of Marsh and Aquatic Vascular Plants of North Carolina with Habitat Data. The North Carolina Agricultural Research Service, Raleigh. 298 pp.

Bolser, R. C., M. E. Hay, N. Lindquist, W. Fenical, and D. Wilson. 1998. Chemical defenses of freshwater macrophytes against crayfish herbivory.--Journal of Chemical Ecology 24: 1639-1658.

Bradford, M. M. 1976. A rapid and sensitive method for the quantification of microgram quantities of protein utilizing the principle of protein-dye binding.-Analytical Biochemistry 72: 248-254.

Buchsbaum, R., I. Valiela, and T. Swain. 1984. The role of phenolic compounds and other plant constituents in feeding by Canada geese in a coastal marsh.-Oecologia 63: 343-349.

Carpenter, S. R., and D. M. Lodge. 1986. Effects of submersed macrophytes on ecosystem processes.-Aquatic Botany 26: 341-370. 
Chambers, P. A., J. M. Hanson, J. M. Burke, and E. E. Prepas. 1990. The impact of the crayfish Orconectes virilis on aquatic macrophytes.-Freshwater Biology 24: 81-91.

- and E. E. Prepas. 1991. The effect of aquatic plant chemistry and morphology on feeding selectivity by the crayfish, Orconectes virilis.-Freshwater Biology 25: 339-348.

Conover, W. J. 1980. Practical Nonparametric Statistics, Second Edition. John Wiley \& Sons, New York. 493 pp.

Creed, R. P., Jr. 1994. Direct and indirect effects of crayfish grazing in a stream community.-Ecology 75: 20912103.

Cronin, G. 1998. Influence of macrophyte structure, nutritive value, and chemistry on the feeding choices of a generalist crayfish. Pp. 307-317 in E. Jeppesen, Ma. Sondergaard, Mo. Sondergaard, and K. Christoffersen, eds. The Structuring Role of Submerged Macrophytes in Lakes. Springer-Verlag, New York.

$\longrightarrow$, and M. E. Hay. 1996a. Seaweed-herbivore interactions depend on recent history of both the plant and animal.-Ecology 77: 1531-1543.

— , and 1996b. Within-plant variation in seaweed palatability and chemical defenses: optimal defense theory versus the growth-differentiation balance hypothesis.-Oecologia 105: 361-368.

$\longrightarrow$, N. Lindquist, M. E. Hay, and W. Fenical. 1995. Effects of storage and extraction procedures on yields of lipophilic metabolites from the brown seaweeds Dictyota ciliolata and D. menstrualis.-Marine Ecology Progress Series 119: 265-273.

-, V. J. Paul, M. E. Hay, and W. Fenical. 1997. Feeding deterrent effects of new diterpenes from Dictyota acutiloba: geographic variation in herbivore resistance to seaweed defenses.-Journal Chemical Ecology 23: 289-302.

- K. D. Wissing, and D. M. Lodge. 1998. Comparative feeding selectivity of herbivorous insects on water lilies: aquatic vs. terrestrial insects and submersed vs. floating leaves.-Freshwater Biology 39: 243-257.

Damman, H. 1987. Leaf quality and enemy avoidance by the larvae of a pyralid moth.-Ecology 68: 88-97.

Dorn, N. J., G. Cronin, and D. M. Lodge. 2001. Feeding preferences and performance of an aquatic lepidopteran on aquatic macrophytes: plant hosts as food and habitat.-Oecologia 128: 406-415.

Doucet, C. M., and J. M. Fryxell. 1993. The effect of nutritional quality on forage preference by beavers.-Oikos 67: 201-208.

Duffy, J. E., and M. E. Hay. 1994. Herbivore resistance to seaweed chemical defense: the roles of mobility and predator risk.-Ecology 75: 1304-1319.

$\longrightarrow$, and V. J. Paul. 1992. Prey nutritional quality and effectiveness of chemical defenses against tropical reef fishes.-Oecologia 90: 333-339.

Fraser, D., E. R. Chavez, and J. E. Paloheimo. 1984. Aquatic feeding by moose: selection of plant species and feeding areas in relation to chemical composition and characteristics of lakes.-Canadian Journal of Zoology 62: 80-87.

Goering, H. K., and P. J. Van Soest. 1970. Forage Fiber Analyses (apparatus, reagents, procedures and some applications). U.S. Department of Agriculture Handbook 379. Government Printing Office, Washington, D.C. $20 \mathrm{pp}$.

Gutierrez-Yurrita, P. J., G. Sancho, M. A. Bravo, A. Baltanas, and C. Montes. 1998. Diet of the red swamp crayfish Procambarus clarkii in natural ecosystems of the Donana National Park temporary fresh-water marsh (Spain).- Journal of Crustacean Biology 18: 120-127.

Hay, M. E., Q. E. Kappel, and W. Fenical. 1994. Synergisms in plant defenses against herbivores: interactions of chemistry, calcification, and plant quality.-Ecology 75 : 1714-1726.

- J. J. Stachowicz, E. Cruz-Rivera, S. Bullard, M. S. Deal, and N. Lindquist. 1998. Bioassays with marine and freshwater macroorganisms. Pp. 39-141 in K. F. Haynes and J. G. Millar, eds. Methods in Chemical Ecology, Volume 2, Bioassay Methods. Chapman and Hall, New York.

— , and P. D. Steinberg. 1992. The chemical ecology of plant-herbivore interactions in marine versus terrestrial communities. Pp. 371-413 in G. A. Rosenthal and M. R. Berenbaum, eds. Herbivores: Their Interactions with Secondary Plant Metabolites. Vol. II: Evolutionary and Ecological Processes. Academic Press, New York.

Hill, A. M., and D. M. Lodge. 1995. Multi-trophic-level impact of sublethal interactions between bass and omnivorous crayfish.-Journal of the North American Benthological Society 14: 306-314.

Hobbs, H. H., Jr. 1972. Crayfishes (Astacidae) of North and Middle America.-U.S. Environmental Protection Agency. $173 \mathrm{pp}$.

Hobbs, H. H., III. 1993. Trophic relationships of North American freshwater crayfishes and shrimps.-Milwaukee Public Museum, Contributions in Biology and Geology 85: 1-110.

Huner, J. V., and J. E. Barr. 1984. Red Swamp Crawfish: Biology and Exploitation. Louisiana Sea Grant Program, Louisiana State University, Baton Rouge. 184 pp.

Karban, R. K., and I. T. Baldwin. 1997. Induced Responses to Herbivory. The University of Chicago Press, Chicago. 319 pp.

Kreider, J. L., and S. A. Watts. 1998. Behavioral (feeding) responses of the crayfish, Procambarus clarkii, to natural dietary items and common components of formulated crustacean feeds.-Journal of Chemical Ecology 24: 91-111.

Littler, M. M., and D. S. Littler. 1980. The evolution of thallus form and survival strategies in benthic marine macroalgae: field and laboratory tests of a functional form model.-American Naturalist 116: 25-44.

Lodge, D. M. 1991. Herbivory on freshwater macrophytes. -Aquatic Botany 41: 195-224.

, G. Cronin, E. Van Donk, and A. Froelich. 1998. Impact of herbivory on plant standing crop: comparisons among biomes, between vascular and non-vascular plants, and among freshwater herbivore taxa. Pp. 149 174 in E. Jeppesen, Ma. Sondergaard, Mo. Sondergaard, and K. Christoffersen, eds. The Structuring Role of Submerged Macrophytes in Lakes. Springer-Verlag, New York.

, M. W. Kershner, J. E. Aloi, and A. P. Covich. 1994. Direct and indirect effects of an omnivorous crayfish (Orconectes rusticus) on a freshwater littoral food web.-Ecology 75: 1265-1281.

— and J. G. Lorman. 1987. Reductions in submersed macrophyte biomass and species richness by the crayfish Orconectes rusticus.-Canadian Journal of Fisheries Aquatic Sciences. 44: 591-597.

Mattson, W. J. 1980. Herbivory in relation to plant nitrogen.-Annual Review of Ecology and Systematics 11: $119-161$.

McClintock, J. B., and B. J. Baker, eds. 2001. Marine Chemical Ecology. CRC Press, Boca Raton. 
Merritt, R. W., and K. W. Cummins, eds. 1996. An Introduction to the Aquatic Insects of North America. 3rd ed. Kendall/Hunt Publishing Co. 862 pp.

Momot, W. T. 1995. Redefining the role of crayfish in aquatic ecosystems.-Reviews in Fisheries Sciences 3: 33-63.

Newman, R. M. 1991. Herbivory and detritivory on freshwater macrophytes by invertebrates: a review.Journal of the North American Benthological Society 10: 89-114.

, Z. Hanscom, and W. C. Kerfoot. 1992. The watercress glucosinolate-myrosinase system: a feeding deterrent to caddisflies, snails and amphipods.-Oecologia 92: 1-7.

Ostrovsky, M. L., and E. R. Zettler. 1986. Chemical defenses in aquatic plants.-Journal of Ecology 74: 279-287.

Paul, V. J., and K. L. Van Alstyne. 1992. Activation of chemical defenses in the tropical green algae Halimeda spp.--Journal of Experimental Marine Biology and Ecology 160: 191-203.
Peterson, C. H., and P. E. Renaud. 1989. Analysis of feeding preference experiments.-Oecologia 80: 82-86.

Provenza, F. D. 1995. Postingestive feedback as an elementary determinant of food preference and intake in ruminants.- Journal of Range Management 48: 2-17.

Ragan, M. A., and J. S. Craigie. 1978. Phenolic compounds in brown and red algae. Pp. 157-179 in J. A. Hellebust and J. S. Craigie, eds. Handbook of Phycological Methods: Physiological and Biochemical Methods. Cambridge University Press, New York.

Rice, W. R., and S. D. Gaines. 1994. 'Heads I win, tails you lose': testing directional alternative hypotheses in ecological and evolutionary research.-Trends in Ecology and Evolution 9: 235-237.

Rosenthal, G. A., and M. R. Berenbaum. eds. 1992. Herbivores: Their Interactions with Secondary Plant Metabolites. Vol. II: Evolutionary and Ecological Processes. New York: Academic Press. 718 pp.

ReCEIVED: 1 August 2001.

ACCEPTED: 11 February 2002. 